\title{
Counter-Containment of Unipolarity
}

Dialectical Realism as a World Outlook

Dayan Jayatilleka

\section{Abstract}

In which direction should Russia turn and what path should it chart in world affairs? Who are its friends and who are its enemies? What is the idea or set of ideas, and indeed, the philosophy of world politics and history that would best guide Russia's international perspective and foreign policy? Russia is divided not so much between the conventional categories of Easternizers and Westernizers, but between a mindset of being part of the West-led world order, and a contending mindset of being a self-sufficient "galactic" system or a mini-empire. The assimilationist approach which predominated in the late 1980 s and 1990s, as well as the ghost of "socialism in one country" — without "socialism"—are the two ways of thinking that encumber Russia from using its full potential in leading the struggle for a democratic world order and becoming the leader or co-leader of such a world order. Only a strong and well-considered structural-systemic relationship between Russia and China can constitute a powerful enough global counterweight to the unipolarity and the United States' strategic offensive posture, and also act as a midwife in the birth of an undeniably multipolar world order. It is also the only way to effect a containment or countercontainment of the U.S. urge towards unipolar hegemony. Struggle on a world scale, sometimes reaching its most intense and decisive form of conflict, is the

Dayan Jayatilleka, Ph.D. in Political Science, is Ambassador Extraordinary and Plenipotentiary of the Democratic Socialist Republic of Sri Lanka to the Russian Federation.

E-mail: ambassador@srilankaembassy.ru

Tel.: +7(495) 688-16-20

Address: 24 Shchepkin Str., Moscow 129090, Russia

DOI: 10.31278/1810-6374-2019-17-4-184-198 
driving force of world politics. In the final analysis, the guiding philosophy of world politics of the state and political leadership may determine success or failure of that state in the world arena. The Soviet Realists grasped the principle of dialectics between contradiction and antagonisms and were, in a sense, "Existential Realists" in terms of the philosophy of history. An effective response to the current unilateral escalation, which is a post-Soviet phenomenon, calls for Russian Realism, which is a Dialectical neo-Soviet Realism.

Keywords: world order, multipolar world, Russia's foreign policy, philosophy of world politics, Russian Realism, counter-containment, dialectical Realism

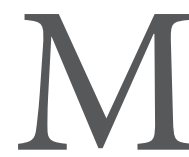
arx famously said that man makes his own history but not under circumstances determined by himself. Philosophy concerns itself with the right (the best/most appropriate/ most moral/most useful) way to act when a human is confronted by circumstances. Philosophy can be internally differentiated according to the varying prescriptions and interpretations it gives for such action.

The same goes for countries or states. States can be classified as strong or weak in a certain period, according to the way they handle the contemporary challenges and the circumstances formed (mainly) by geography and history, that they confront and are confronted by.

The struggle over Russia's destiny in the world, seen as the struggle for Russia's soul between Westernizers and Easternizers-or Westernizers, Easternizers, and Eurasianizers-is an old trope. What is going on today is possibly not quite so existential in character but is certainly not unrelated. In which direction should Russia turn and what path should it chart in world affairs? Who are its friends and who are its enemies? What is the idea or set of ideas, and indeed, the philosophy of history that would best guide Russia's international perspective and foreign policy? These questions determine the scale and scope of the current debate.

The old adage "Tell me who your friends are and I will tell you who you are" is an excellent guideline in personal life, but it is not perhaps the best yardstick in global politics, or perhaps tells only 


\section{Dayan Jayatilleka}

half the story. In international politics, it is more useful to invert it to "Tell me who your enemies are and I will tell you who you are." But how does one tell who one's enemies are? Praxis, which means the organic, indissoluble unity of theory and practice, is the criterion. John F. Kennedy supposedly said: "Never mind what one says; watch his hands." Your enemy is someone who treats you as an enemy in what they say and do-and most crucially in the latter-that is to say, in their doctrine, preparation and action. Your enemy is someone who attacks, threatens or opposes your most vital interests. Your friend is someone who helps you defend yourself from your enemy and with whom you share common interests.

Russian Realists tend to blame dilettantish liberalism for the deviation from the great tradition of Western Realism from Kennan to Kissinger which they are familiar with. This ideological finger-pointing mirrors the earlier Western liberal effort to pin the blame of the Bush administration's policies on the afterlife of the intellectual influence of Leo Strauss. A closer scrutiny may reveal that strategists and policymakers of hardcore neoconservative character, and determined practitioners of Western global assertiveness have consistently been under the intellectual and doctrinal influence of the ideas of Prof. Robert StrauszHup, former U.S. Ambassador to NATO (and earlier, to Ceylon), who regarded the Cold War as a "protracted conflict" and was firm in his conviction that the U.S. was the most suited to lead the world because its federal model was applicable on a mega-scale as an arrangement or rearrangement of the entire world order under U.S. "global leadership."

It is one of the many ironies of the history of political-military thought that Russian thinking, while understandably rejecting the liberal idealism of Fukuyama et al, has, on the rebound as it were, tightly embraced Realism-but importantly, American or Western Realism, that of Kissinger, Huntington, and Mearsheimer. A far richer and authentic strand of Russian Realism, in the form of Soviet Strategic Realism, exists encrusted, buried or submerged in the history of modern Russian thought.

Those who rightly scoffed at the Western liberal notion of the 'end of history', including the ones who fully understood Hegelianism 
mediated by Kojève, made a mirroring mistake. While Western liberals thought that indeed history had ended, thinkers and political scientists in the target states of the West (except for those in Latin America), thought instead that imperialism had ended.

By way of counterpoint, I hope to be forgiven for the sin of selfquotation as I reproduce below an extract of my analysis published in 2012 (The End of Global Equilibrium. A Counter-Narrative from the South, SECURITY INDEX, No. 1 (98), Vol. 18). This was authored and submitted before the return of Putin's presidency, China's BRI initiative, the Ukraine crisis, and the birth of the U.S. Indo-Pacific strategy and Indo-Pacific Command.

"...While it may or may not be true that the United States is in relative historical and strategic decline, the paradox is that it possesses far greater grand strategic clarity than does any other global power... That clarity, deriving from American exceptionalism, is summed up in the phrase 'full spectrum dominance,' which is but a re-statement and extension into the 21st century of Time/Life founder Henry R. Luce's slogan of the 20th century as 'the American Century.' What this means is nothing less than U.S. global predominance over any power or combination of powers... The implications are twofold: the United States and its allies cannot and will not permit a truly multi-polar world order, and the minimum role in world affairs that is commensurate with Russia's and China's interests and destinies will fall short of the maximum role that the United States and its allies will be willing to concede.

"To put it at its most succinct, an authentically strong Russian state will never be viewed as anything but a threat by U.S. strategic planners, just as they will never view a strong China as anything but a threat. The West will always try to keep both Russia and China contained and encircled, and will attempt to encourage their internal political evolution, while it will never countenance anything that remotely resembles containment of its own ambitions. While the United States and its allies attempt to maximize the politico-strategic space available to them, they will seek to limit if not minimize the politico-strategic space available to Russia and China. 


\section{Dayan Jayatilleka}

"In the current global conjuncture, the United States and its allies are on the offensive... [which] will eventually cause the roll-back of all rivals and competitors, real and potential, and guarantee U.S.-led Western global hegemony. This means a diminution of the strength of the Russian and Chinese states. At the heart of the matter is the question of national and state sovereignty. Russia and China share a common conceptual, politico-philosophical, and strategic vision on a core issue, sovereignty, while the U.S.-led West fails to concede such sovereignty to these states and is attempting to dismantle sovereignty as a cornerstone of the world order..."

Renowned historian William H. McNeill said that history must be read backwards; you start from the present and move back. The brilliant, if tragic, German thinker Walter Benjamin who committed suicide in 1940, fleeing the Nazis, said that history must be brushed against the grain. If one follows these correct guidelines, what does one discover? Five major episodes in international relations (or global politics), four of which were apart in time, demonstrate what the U.S.-led West thought were the rules of the game, even when-or rather, precisely when-Russia was no longer a competitor but a friend and partner. Those episodes were: ignoring the Franco-Russian peace initiative on the eve of the Gulf War 1991; ignoring the impact on Russian interests and views in the Kosovo War of 1999; the cruise missile attack on the Chinese embassy in Belgrade (when the alleged information sharing by China could have been dealt with by the U.S. through a telephone call to China's leaders); the invasion of Iraq (pivoting away from the post-9/11 War on Terror in Afghanistan, which had broad global, including Russian support); and the deceitful, murderous regime change in Libya, which went beyond the Security Council's resolution that Russia had agreed to. Not only were the sentiments and interests of the Russian and Chinese "partners" not taken into consideration, they were ridden over roughshod, and worse, these actions were seriously inimical to those interests. That all these episodes took place under both Republican and Democratic administrations-of realist, neoconservative and neoliberal persuasions - and apart from a single one (Iraq) were not during the Putin presidency, was clear evidence 
of what the post-Cold War world order was projected to be. The main weakness of this order was not that it was liberal, but that it was unipolar, and that in turn meant that the U.S. would "lead", that is, dominate the world, as it saw fit.

The Russian dream that Europe would join it or it could join Europe as an autonomous continental formation faded or should reasonably be expected to have faded (although in some quarters it remains an aspiration) when Germany initiated the breakup of Yugoslavia by recognizing Croatia and Slovenia, which culminated in civil wars and the disaggregation of that country. Given that former President Gorbachev famously conceded the peaceful reunification of Germany on the guarantee that NATO would not spread eastward, the subsequent role played by Germany in the breakup of Yugoslavia, and Europe's role in the NATO (50th anniversary) war on Yugoslavia, as well as the "out of area" expansion of NATO itself, are truly revelatory of the post-Cold War ethos: one of U.S.-led Western global hegemony and diktat.

The greatest paradox-an uncharitable person may call it hypocrisy-in today's world is that the Western powers which regard themselves, and in essence are indeed, democratic are vehemently opposed to a democratic world order, or even one that is relatively more democratic than it is now. It is they who stand opposed to the democratization, as distinct from the liberal democratization, of the world order. It is they who stand opposed to a world order that respects sovereign equality and non-interference in the relations among nations, in the same manner that democratic societies regard individuals as irreducibly sovereign and equal. A related paradox is the question of diversity. The same West that praises cultural diversity and political pluralism within their societies, opposes the notion that the world order should be characterized by political pluralism and a diversity of values, norms and choices, influenced by and reflective of demographic, social, cultural and civilizational diversity.

What is bitterly ironic is that the Western powers oppose a democratic world order based on the sovereign equality of nations, on the philosophical basis that there are great power rivals who do 


\section{Dayan Jayatilleka}

not practice democracy and the sovereignty of individual persons. To put it another way, a democratic pluralist world order, a world order characterized by sovereign equality, diversity and choice of paths, is opposed by countries that pride themselves on establishing and preserving such an order domestically, within their own societies, and justify such opposition on the grounds that their rivals do not practice democracy and pluralism within their own societies.

Russia for its part is unable to fully expose and exploit this Western contradiction because it has not yet resolved its own contradictions. The main one is the contradiction between its own notion of a democratic world order and its own sense derived from its uniquely vast size, of being a universe unto itself. Russia is divided not so much between the conventional categories of Easternizers and Westernizers, but between a mindset of being part of the Westled world order and a contending mindset of being a self-sufficient "galactic" system or mini-empire. The assimilationist approach which dominated in the late 1980s and 1990s, as well as the ghost of "Socialism in One Country"-without the "Socialism" - are the two ways of thinking that encumber Russia from using its full potential in leading the struggle for a democratic world order and becoming the leader or co-leader of such a world order.

It is by no means the case that "Socialism in One Country" was an erroneous concept. On the contrary, it was historically correct, necessary, valuable, and it made far more sense than the perspectives offered by its critics such as Trotsky, with his doctrine of "Permanent Revolution." However, it is an outdated concept which was abandoned without any fuss or reference whatsoever by its main author, Stalin, once the conditions that necessitated it had been replaced by entirely different post-WWII conditions which called for its abandonment and the adoption of a new perspective.

"Socialism in One Country" was a perspective latent in the thinking of Lenin, who unlike Trotsky, understood that capitalism developed so unevenly that it not only provided the opportunity for victory in one country (and it must be said that Trotsky, too, had predicted the possibility of the Russian Revolution), but also provided 
for its stabilization for an extended period while fighting against and surviving within a hostile world environment. For Lenin, however, this was Track B, while Track A was the world revolution, especially in Europe. After the defeat of the German revolutionary uprisings and, more particularly, the Red Army offensive in Poland in 1920, Lenin's Track A shifted its focus from the West to the East, i.e. to the periphery of world capitalism, while Track B, which was not yet called "Socialism in One Country," came increasingly into play in the form of the Treaties of Genoa and Rapallo, the NEP, and the offer of concessions to Western investors in the gold fields of Siberia.

The latent in Lenin became manifest in Stalin with Track B becoming Track A and vice versa. This was in accordance with the actual balance of power and the USSR's isolation. "Socialism in One Country" became the doctrine and served the purpose of mobilizing the Russian nation for building an industrialized society at a breakneck speed. This combination of nation and class, of national and social aspirations, provided the material and moral foundation for the victory in the Great Patriotic War.

What is paradoxical is that the mentality of "Socialism in One Country" has survived until today, although Stalin himself would not mention it after the victory over Nazism. Instead, he grasped the new postwar realities and articulated a strategy based on defending and maximizing the gains of the Great Patriotic War and its aftermath, above all, the end of limiting the Russian Revolution to one country and the extension of Socialism to the West and the East, thus ending the geopolitical and geostrategic isolation of the Soviet state.

The post-Cold War period was marked by a swing to extremesfrom illusions of incorporating Russia into the West-led world order to a sharp reaction against the perspective which was fraught with Russia's collapse, a swing to a ghostly echo of "Socialism in One Country." As echoes usually go, it was a fragmented version of the original phrase: it was no longer "Socialism in One Country," but simply "... in One Country." The mentality took varied ideological forms, such as "Great Power Nationalism in One Country", "Civilizational Realism in One Country" or "Sovereign Democracy in One Country." 


\section{Dayan Jayatilleka}

This swing from one extreme to another was reminiscent of the 'Left deviation' and 'Right deviation' of the Soviet lexicon, referring originally to Trotsky and Bukharin, respectively. In an acerbic witticism, which philosopher Slavoj Žižek is fond of repeating, when Stalin was asked by an interviewer "Which is worse, the Right deviation or the Left deviation?" he replied: "They are both worse." His point was that there was a correct strategic perspective, a third (Leninist) space which demarcated itself from both errors.

Similarly, the post-Cold War period had a third path available, which is neither that of reintegration with the West nor a narcissistic nationalism.

It is entirely understandable that the lurch to the West, when it proved disastrous, could deviate into "Great Power Nationalism in One Country," but it was not the only strategic perspective available. Stalin replaced the obsolete "Socialism in One Country" perspective with that of a "camp" stretching from the Elbe to the North China Sea. True, the post-Cold War period saw the western flank dropping off, the Soviet Union cracking up, and latterly, even vital parts being turned into the strategic adversary's bases. However, things could have been far worse, and Russia could have had a threat on its eastern front too, as it did for decades. Instead, the rapprochement between Russia and China obviate the strategic, existential and psychological need for a return to the "In One Country" perspective, and leaves the core of the post-WWII, Cold War perspective of Stalin intact and relevant.

However, the question arises as to whether such a perspective is still valid given the historical experience of the volatile 'Right' and 'Left' deviations of the Chinese Communist Party, and, therefore, whether the interest of Russia is not far better served by some variant of an "In One Country" perspective which gives Russia maximum freedom, unencumbered by a strategic political camp, bloc, alliance or united front.

There are two essential, grand strategic and existential problems which Russia is grappling with: 1) which model to design and adopt in Russia's equation with China and 2) how to prevent over the long term a return in Russia itself of an updated version the 1990s policy of 
appeasement of/collusion with the West, which the latter seeks to achieve by means of hybrid war on Russia's rim, generational succession and peaceful regime change (which the Chinese call "peaceful evolution").

Not only are the problems interlinked but also the answers; and even more so-there is a single overarching answer to both questions. The nature of the relationship with China will provide the parametric constraints on both possible volatility of China's behavior and possible return to appeasement on the part of Russia. Since both the volatility of Chinese policy and the swing of Russian policy are historically observable factors which proved injurious to the national and state interests of both countries and their peoples over the long historical term, it is only a structural or systemic approach that can prevent and pre-empt their recurrence.

A close study of the history of the Chinese Communist Party would show that the Left and Right deviations were so pronounced, and some would argue, possible and even occasioned, precisely by the rupture in the Sino-Soviet relationship. Of course, that rupture was subsequent to a left-wing deviation on the part of the leadership of the Chinese Communist Party to the "Great Leap Forward," but that Left deviation contained the seeds of its own demise, as was evidenced in the temporary victory of the Chinese Realists led by Liu Shao Chi.

The point is twofold: the Left deviation became an antagonistic, hostile rupture because Khrushchev subjectively overreacted by unilaterally tearing up the blueprints and pulling Soviet experts out of China in 1959-1960, and the post-Great Leap victory of the Chinese Realists was only temporary, because of the rupture with the USSR initiated by the latter. Had the alliance remained despite the Great Leap Forward, the return of the Chinese Realists could have been more durable. Instead, it was the continued rupture with the USSR that provided the space for the launch of the ultimate ultra-left and xenophobic deviation, the Great Proletarian Cultural Revolution. The anarchy that ensued from that experiment caused the most extreme right-wing deviation in the form of the theory of the two superpowers, next shifting to a theory of the USSR as the main, if not sole, enemy, and to the "quasi-alliance" with the United States. 


\section{Dayan Jayatilleka}

Throughout its post-revolutionary history, the Chinese Communist Party had Realists in both the realms of economic thinking and international relations. It could even be argued that one and the same leading personality-Mao, Zhou, Deng-had periods of realism in policy, preceding and interrupting other phases of either "Left" or "Right" deviations. The Realist elements in the party and indeed in the mentality of individual leaders were the strongest when the Sino-Soviet relationship was intact and weakest when the relationship was ruptured.

A policy of strategic patience and Realism, which maintained the systemic or structural equation with Beijing, would have made it difficult for China to back, if not urge, Pakistan to play the frontline role it did against the USSR during the Afghanistan conflict, and without Afghanistan being turned by Brzezinski into the Soviet Union's Vietnam - a strategy which would have been impossible to implement without Pakistan and difficult to implement without China's support, given the leverage China had with Pakistan, the bleeding out of the USSR's élan vital would not have taken place. It was the weakening of the prestige, influence and role of the Soviet military and its representatives within the Soviet government and state resulting from the failure in Afghanistan that tilted the domestic power balance and made it easier for the liberal-reformist worldview to take hold in the late 1980 s and the 1990 s.

The conclusion then is that the volatility of the political line of the Chinese Communist Party should not be a deterrent to the restoration of the alliance between Russia and China. On the contrary, it is the removal of the alliance that detached the parametric constraints on and countervailing factors against such volatility. The potential variability of the Chinese line is not an argument against a Russia-China alliance but an argument in favor of it. This is not least because the rupture of that alliance not only enabled China to veer into an alliance with the West but also because that alliance impacted directly on the fate of Russia through Afghanistan, in the form of the depletion and breakup of the USSR. Only a strong and well considered structural-systemic relationship between Russia and China can minimize damaging "deviations" while constituting a powerful enough global counterweight to unipolarity and 
the U.S. strategic offensive posture, and also acting as midwife in the birth of an undeniably multipolar world order-eventuating in official U.S. acceptance of that reality and suitable circumscription of its global conduct. In short, this is the only way to effect a containment or countercontainment of the U.S. urge towards unipolar hegemony.

It is noteworthy that even before the Russian Revolution(s) of 1917, in the very year that Lenin penned his Imperialism: the Highest Stage of Capitalism, he had authored an article titled Backward Europe and Advanced Asia, in which he argued that in Asia, the rising bourgeoisie was still fighting for the classic nation-building objectives of national independence and sovereignty, and was therefore contesting imperialism, while in the West, the bourgeoisie had long turned against those objectives and was pursuing their very opposite. He would later elaborate that the upper stratum of the working-class movement had also been bribed into selling out that struggle. Lenin's pivot to the East did not stop at the conceptual or strategic. After the failure of the Red Army in Poland and its defeat at the hands of Catholic nationalist Pilsudski, and while shifting to the defensive on the western front, Lenin turned Soviet policy and the Comintern towards China, and extended military support to Sun Yat-sen, who was by no means a Communist but a modernizing nationalist. It was a continuation of this Leninist policy that the Communist University of the Toilers of the East (CUTE) was established, while Soviet instructors were at China's Whampoa Military Academy where Zhou Enlai, already in the ranks of the Comintern, was also an instructor. Stalin took this Eastward shift still further, arguing slightly cynically in 1925 that insofar as the British Labor Party was benefitting from and acquiescing in imperialism, while Afghanistan was still fighting against British imperialism, "the Emir of Afghanistan is more progressive than the British Labor Party."

This perspective is eminently applicable to the rise of Asia in the 21st century and the centrality of the struggle for national and state sovereignty which cannot but constitute the main axis of the struggle to contain or counter-contain the unipolar urge.

Today, Russia and China have three options. One is to hope for reincorporation into the U.S.-led world order, especially the world 


\section{Dayan Jayatilleka}

economic order, perhaps after the U.S. president wins a second term. This is flawed for three reasons. A reelected president may feel free to wage wars as much as to wage peace. Secondly, whoever the president, the general trend has been one of increasing pressure upon China and Russia and decreasing space for both, albeit perhaps slightly unevenly. Thirdly, even if there is a restoration of the status quo ante, this only means that Russia and China remain susceptible to the unilateral stop-go policy as regards military buildups, bilateral agreements and economic sanctions.

The second option is the "In One Country" ideology, i.e. great power nationalism and civilizational exceptionalism, which makes for a seemingly free-ranging autonomy but is vulnerable to an adversary with a global reach, world economy, a world network of allies and partners, and a universalist ideology.

The third option is an adaptation of a view of Antonio Gramsci who said that no social or political formation can aim at hegemony solely by representing its own parochial interests but by representing a larger, more inclusive overall interest; a common interest. He said that this is indeed the only way to achieve even one's own localized interest. He was speaking of the working class, and in so doing he was elaborating, deepening and complexifying Lenin's idea that the working class must not limit itself to economic and trade unionist demands ("economism" as he called it), but should advance to the level of politics and representation of the interests of the social whole, barring the enemy class. For this purpose, said Lenin, the trade unions would not suffice, and only a political party composed of cadres who were educated enough to transcend workplace concerns and see the whole, could fulfill the task.

What is true of class is also true of country, nation, and state. Only by representing the interests of the whole humanity can a country defend its national interests in a sustainable manner. Thus, the third option is an alternative world system based on an alternative network of alliances, a counter-system seeking to best represent the interests of humanity. This option, which used to be termed 'internationalism, is understood not as an abstract cosmopolitanism but as a dialectical 
equation between the two dimensions of existence: national and international, geographically rooted and universally human.

The highest prestige and status that Russia had in world history and world affairs was during the Soviet era, not before. A counterfactual history argues that had the reforms of Count Witte and Stolypin been carried out to the full, or had Russia's development not been interrupted by the Bolshevik revolution, the rate of industrialization would have seen Russia through to superpower status. Yet that cannot be known, still less proved. What is known is that tsarist Russia collapsed because the only status it enjoyed under the imperialist order was that of a junior partner of Western imperialism which drew it into the war, incurring casualties and internally depriving it of national ideological legitimacy-a historical lesson that was lost on the reformists of the 1990s. What is also known is that, as Churchill acknowledged, Stalin took Russia from the age of the plough to that of the hydrogen bomb. What Russia is today is the revitalization of the core of that modern Soviet state, of what was left of the Soviet superpower.

The United States, France and China have clear marker dates of their emergence as modern states: 1776, 1789, and 1949. These dates mark "revolutions" of some sort and endow them with a certain romantic appeal in the universalist sense. Russia had the most dramatic date of all-the 1917 Bolshevik revolution, which triggered so many waves of history, moved so many hearts, and influenced so many minds and actions. Every state needs its myths, and by abandoning "1917" the Russian state has unilaterally deleted some of its sources of soft power.

The phenomenon and process of struggle, sometimes reaching its most intense and decisive form of conflict, is the driving force of politics. In the final analysis, the guiding philosophy of world politics of a state and its political leadership may determine success or failure of that state in the world arena. No school of philosophy is more discerning of the phenomenon and process of struggle, including conflict, than the dialectical school.

I would argue that the most authentic Realists are "dialectical Realists" and the most authentic Realism is a Dialectical Realism (if I may coin a term). The Soviet Realists were dialectical Realists because 


\section{Dayan Jayatilleka}

they had grasped the principle of dialectics-the clash of opposites, the concept of contradiction, especially the Leninist distinction between "contradictions" and "antagonisms" (or between friendly contradictions and antagonistic contradictions, as Mao rephrased and popularized it). They understood the principle dating back to Sun Tzu's millenniaold edict "Know yourself, know your enemy." They were, in a sense, "Existential Realists" in terms of developing the dialectics of History.

Since Western behavior is even more assertive today than during the Soviet days and since the Western offensive strategic drive has not been halted and has accelerated, it is both logical and imperative that Russian Realism have a neo-Soviet aspect. Arguably, effective Russian Realism must be a dialectical, neo-Soviet Realism.

No thinker-practitioner of politics, including world politics, was more dialectical and more capable of precisely focusing concentrated political will than Lenin. From a political science point of view, the Marxism of Lenin is as relevant or irrelevant, as primary or secondary, as was the Hegelianism of Marx. Lenin can be apprehended as a political thinker, indeed as a thinker par excellence of political combat, with only a secondary reference to Marx. Lenin as a political thinker can be liberated from the shell of Marxism, and Leninism can be rethought as the political philosophy of struggle and conflict, or the terms 'Leninism/ Leninist' can even be set aside because of their dogmatic connotations, and Lenin retrieved as the father of Dialectical Realism, recognized as the finest political philosopher of struggle, conflict and combat.

Lenin was the Master Realist because there was perhaps no one in the period of "late modernity" who was able to grasp more lucidly and speedily the concrete political situation in all its complexity, the real state of the balance of power and the accurate application of political will. Lenin remains the Russian thinker who had the greatest impact upon the world, human thought and action. He cannot be cast aside as a political thinker without considering the cost of that loss of intellectual impact and influence. Reevaluating Lenin as a political thinker should be undertaken in the same spirit as Gramsci's reevaluation and rehabilitation of Machiavelli, or as when Machiavelli returned to the accounts of an ancient historian and penned his Discourses on Livy. 